\title{
Tuning the spin-crossover temperature of polynuclear iron(II)- triazole complexes in solution by water and preparation of thermochromic fibers
}

\author{
Irene Bräunlich $\cdot$ Samuel Lienemann • \\ Christiane Mair · Paul Smith · Walter Caseri
}

Received: 9 July 2014/ Accepted: 4 November 2014/Published online: 13 January 2015

(C) Springer Science+Business Media New York 2015

\begin{abstract}
The spin-crossover temperatures of alkylsubstituted $\mathrm{Fe}^{2+}$-triazole complexes with the counter ions 4-dodecylbenzenesulfonate $\left(\mathrm{DBS}^{-}\right)$and 2-naphthalenesulfonate $\left(2 \mathrm{~ns}^{-}\right)$are strongly influenced by water in the dissolved state, whereby the low-spin state is stabilized by water. This effect was found to be more pronounced in complexes with the counter ion $\mathrm{DBS}^{-}$compared to $2 \mathrm{~ns}^{-}$. It appears that non-coordinating water molecules interact with the counter ion and thus alter the ligand-field splitting. Notably, the spin-crossover temperature depends only on the $\mathrm{Fe}^{2+} / \mathrm{H}_{2} \mathrm{O}$ ratio and not on the concentration of the complex in solution. As a consequence, the spin-crossover temperature can be controlled by the $\mathrm{Fe}^{2+} / \mathrm{H}_{2} \mathrm{O}$ ratio (for $\mathrm{DBS}^{-}$complexes within a temperature range of $7-47^{\circ} \mathrm{C}$ ), and on the other hand small amounts of water (in the ppm range) can be detected in apolar solvents. Furthermore, fibers of blends of the complex $\left[\mathrm{Fe}\left(\mathrm{C}_{18} \mathrm{trz}\right)_{3}\right](\mathrm{DBS})_{2}$ with ultra-high molecular weight polyethylene (UHMWPE) could be prepared. In these fibers, spin-crossover is maintained leading to pronounced thermochromism as in the bulk material, indicating essentially no interaction between UHMWPE and $\mathrm{Fe}^{2+}$-triazole complex.
\end{abstract}

Electronic supplementary material The online version of this article (doi:10.1007/s10853-014-8704-3) contains supplementary material, which is available to authorized users.

I. Bräunlich · S. Lienemann · C. Mair · P. Smith ·

W. Caseri $(\bowtie)$

Department of Materials, Eidgenössische Technische

Hochschule (ETH) Zürich, Vladimir-Prelog-Weg 5,

8093 Zurich, Switzerland

e-mail:wcaseri@mat.ethz.ch

\section{Introduction}

Spin-crossover complexes of iron(II) have been intensively studied due to their temperature- [1], light- [2] and pressure- [3] switchable properties such as magnetic susceptibility and color. Among those compounds, polynuclear complexes of $\mathrm{Fe}^{2+}$ with derivatives of 1,2,4-triazole (trz) $[4,5]$ have found wide interest as the spin-crossover properties can easily be adjusted by employing different ligands and counter ions. Moreover, the transition can arise around room temperature. However, the well-studied complexes with rather small triazole substituents, e.g., 4- $\mathrm{H}$ 1,2,4-triazole (Htrz) [6-8] or 4-amino-1,2,4-triazole $\left(\mathrm{NH}_{2}\right.$ trz) [9-11] are in general insoluble in common solvents with rare exceptions such as $\left.\left[\mathrm{Fe}\left(\mathrm{NH}_{2} \mathrm{trz}\right)_{3}\right)\right](2 \mathrm{~ns})_{2}$ $\left(2 \mathrm{~ns}^{-}=2\right.$-naphthalenesulfonate) in $\mathrm{N}, \mathrm{N}$-dimethylformamide (DMF) [12]. In order to obtain $\mathrm{Fe}^{2+}$-triazole complexes which are soluble in organic solvents, in particular aprotic solvents, alkyl side chains are frequently attached to the ligand [13-17]. Accordingly, complexes with various alkyl side chains have been prepared (Table 1). Besides linear aliphatic substituents also branched alkyl chains or alkoxy groups were introduced in order to further enhance the solubility. Similar to $\mathrm{Fe}^{2+}$-triazole complexes with rather small substituents (e.g., $\mathrm{NH}_{2}$ or $\mathrm{H}$ ) alkyl-substituted complexes consist of a linear $\mathrm{Fe}^{2+}$ backbone connected by triple-triazole bridges (Fig. 1) [13]. They undergo spincrossover at temperatures between -110 and $107^{\circ} \mathrm{C}[14$ 25] accompanied by a color change from pink to white and an increase of the $\mathrm{Fe}-\mathrm{N}$ distance $\left(d_{\mathrm{Fe}-\mathrm{N}}\right)$. For example, in $\left[\mathrm{Fe}\left(\mathrm{C}_{18} \mathrm{trz}\right)_{3}\right](\mathrm{ptol})_{2}\left(\mathrm{ptol}^{-}=p\right.$-toluenesulfonate $)$ the related values are $d_{\mathrm{Fe}-\mathrm{N}, \mathrm{LS}}=1.97 \AA$ in the low-spin state and $d_{\mathrm{Fe}-\mathrm{N}, \mathrm{HS}}=2.09 \AA$ in the high-spin state [26]. Of course, as a consequence of the expansion of the $\mathrm{Fe}-\mathrm{N}$ bond also the distance of two neighboring $\mathrm{Fe}^{2+}$ ions increases. 
Table 1 Literature overview of alkyl-substituted $\mathrm{Fe}^{2+}$-triazole complexes

\begin{tabular}{|c|c|}
\hline $\begin{array}{l}\text { Substituent on } \mathrm{N}^{4} \text { of } \\
\text { 1,2,4-triazole }\end{array}$ & Counter ion \\
\hline $\mathrm{C}_{18} \mathrm{H}_{37}$ & $\begin{array}{l}\mathrm{BF}_{4}^{-}[14,18], \mathrm{ClO}_{4}^{-}[15,18,19], \\
\mathrm{CF}_{3} \mathrm{SO}_{3}^{-}[18,19], \mathrm{NO}_{3}^{-}[20,21], \mathrm{Cl}^{-} \\
{[14,19,22], \mathrm{ptol}^{-}[14,17-19,22]}\end{array}$ \\
\hline $\mathrm{C}_{n} \mathrm{H}_{2 n+1}, n=13,16$ & $\begin{array}{c}\mathrm{BF}_{4}^{-}[14,18], \mathrm{ClO}_{4}^{-}[18], \mathrm{CF}_{3} \mathrm{SO}_{3}^{-} \\
{[18], \mathrm{ptol}^{-}[14,18,22], \mathrm{Cl}^{-}[22]}\end{array}$ \\
\hline $\mathrm{C}_{10} \mathrm{H}_{21}$ & $\mathrm{Cl}^{-}, \mathrm{ptol}^{-}[22]$ \\
\hline $\mathrm{C}_{n} \mathrm{H}_{2 n+1}, n=4-8$ & $\mathrm{BF}_{4}^{-}, \mathrm{ClO}_{4}^{-}, \mathrm{CF}_{3} \mathrm{SO}_{3}^{-}, \mathrm{ptol}^{-}[18]$ \\
\hline $\mathrm{C}_{3} \mathrm{H}_{7}$ & $\mathrm{BF}_{4}^{-}, \mathrm{CF}_{3} \mathrm{SO}_{3}^{-}[18]$ \\
\hline $\mathrm{C}_{n} \mathrm{H}_{2 n+1}, n=1,2$ & $\mathrm{BF}_{4}^{-}, \mathrm{ClO}_{4}^{-}[18]$ \\
\hline & $\begin{array}{l}\mathrm{C}_{n} \mathrm{H}_{2 n+1} \mathrm{SO}_{3}^{-}, n=1,8,12,16[13] \\
\mathrm{ClO}_{4}^{-}[23]\end{array}$ \\
\hline 4-(3-Dodecyloxy)propyl- & $\begin{array}{l}\mathrm{Cl}^{-} \text {[16], 9,10-dimethoxyanthracene-2- } \\
\text { sulfonate [24], 1-pyrenesulfonate [24] }\end{array}$ \\
\hline 5-Decylheptadecyl- & $\mathrm{ClO}_{4}^{-}[25]$ \\
\hline
\end{tabular}

For a more detailed overview on such complexes see Ref. [4] $\mathrm{ptol}^{-}, p$-toluenesulfonate

Notably, alkyl-substituted complexes feature a number of properties which have not been found in other $\mathrm{Fe}^{2+}$-triazole complexes. For instance, they often form gels already at low concentration $[15,16,18]$, and in rare cases the spin transition was found to occur simultaneously with the sol-gel transition [14]. Also, many of them are liquid crystalline in the bulk [22, 25] and in solution [13] due to the rod-like shape of the linear $\mathrm{Fe}^{2+}$-triazole backbone (Fig. 1), and Langmuir-Blodgett films could be prepared due to the amphiphilic nature of such complexes [20, 21]. A recent publication of Gaspar and Seredyuk comprehensively reviews spin-crossover metallomesogens as well as related Langmuir-Blodgett films [27]. However, most noteworthy, the alkyl-substituted complexes are typically soluble in aprotic solvents, such as toluene, dodecane, diethyl ether, and chloroform. This allowed the fabrication of pure films by solution casting [16] as well as the preparation of blends with polymers, i.e., with poly(methyl methacrylate) [28], polystyrene [29], and with a polyoxetane-based liquid crystalline polymer [30]. These blends were prepared with $\mathrm{Fe}^{2+}$ complex contents between 0.5 and $25 \% \mathrm{~m} / \mathrm{m}$ and in two cases films of blends were obtained by casting of solutions [28,29]. However, blends with high fractions of complex $(>25 \%$ $\mathrm{m} / \mathrm{m}$ ) have not been addressed yet, to our knowledge. Moreover, further processing of such materials, e.g., into fibers, has not been explored, as far as we are aware of. Notably, the manufacture of fibers is somewhat more delicate since the viscosity of the solution has to be adjusted in order to enable fiber formation.

In this study, solutions of alkyl-substituted $\mathrm{Fe}^{2+}$-triazole complexes are investigated. In particular, two different issues are addressed: On the one hand, fundamental investigations on the influence of traces of water on the spin-crossover properties of $\mathrm{Fe}^{2+}$-triazole complexes and on the other hand use of solutions for the preparation of thermochromic fibers. So far, the influence of water has only been considered indirectly in solutions of $\mathrm{Fe}^{2+}$-triazole complexes by addition of hydrogen-bond scavengers [13], but the water content was not controlled directly, although non-coordinated water has been shown to influence spin-crossover of various compounds in the solid state $[18,31-36]$. While in the majority of cases, water acted as a stabilizer of the low-spin state (i.e., the spin-crossover temperature was increased) also the opposite was found in rare cases [33]. The origin of this unusually strong water dependence has been ascribed to the formation of hydrogen bonds [31]. However, the precise mechanism is still
Fig. 1 Schematic representation of the structure of $\mathrm{Fe}^{2+}$-complexes with alkylsubstituted triazole ligands below (left) and above (right) the spin-crossover temperature with $d_{\mathrm{Fe}-\mathrm{N}, \mathrm{LS}}<d_{\mathrm{Fe}-\mathrm{N}, \mathrm{HS}}$
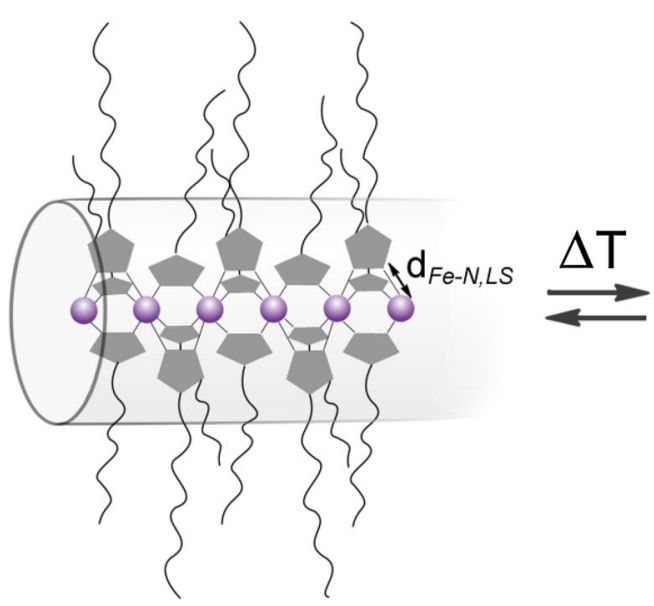

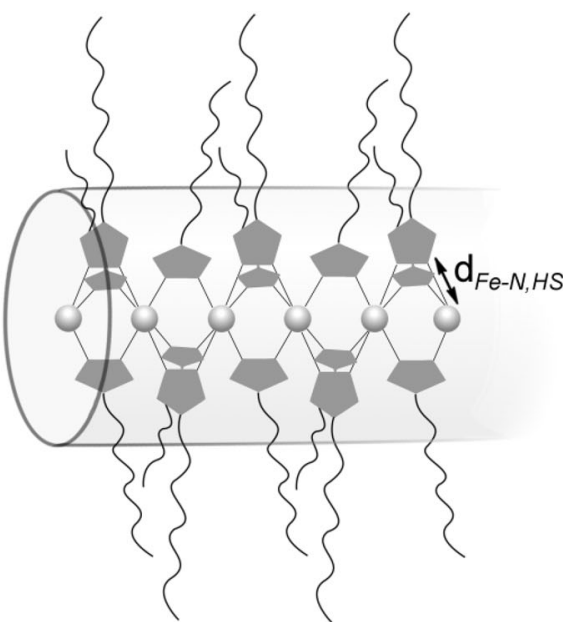


Table 2 Solubility of $\mathrm{Fe}^{2+}$ triazole complexes with different substituents $\mathrm{R}$ at the $\mathrm{N}^{4}$ position of 1,2,4-triazole and counter ions $\mathrm{X}^{-}$at room temperature

\begin{tabular}{|c|c|c|c|c|c|c|c|c|c|}
\hline $\mathrm{X}^{-}$ & $\mathrm{R}$ & Xylene $^{\mathrm{a}}$ & Toluene $^{\mathrm{a}}$ & heptane & $\mathrm{CH}_{2} \mathrm{Cl}_{2}$ & $\mathrm{CHCl}_{3}$ & $\mathrm{Et}_{2} \mathrm{O}$ & THF & $\mathrm{H}_{2} \mathrm{O}^{\mathrm{b}}, \mathrm{EtOH}, \mathrm{MeOH}$ \\
\hline \multirow[t]{3}{*}{$2 \mathrm{~ns}^{-}$} & $\mathrm{C}_{14} \mathrm{H}_{29}$ & $\sim$ & $\checkmark$ & $\mathrm{x}$ & $\mathrm{x}$ & $\checkmark$ & $\mathrm{x}$ & $\mathrm{x}$ & $\mathrm{x}$ \\
\hline & $\mathrm{C}_{16} \mathrm{H}_{33}$ & $\sim$ & $\sim$ & $\mathrm{x}$ & $\mathrm{x}$ & $\checkmark$ & $\mathrm{x}$ & $\sim$ & $\mathrm{x}$ \\
\hline & $\mathrm{C}_{18} \mathrm{H}_{37}$ & $\sim$ & $\sim$ & $\mathrm{x}$ & $\mathrm{x}$ & $\checkmark$ & $\mathrm{x}$ & $\sim$ & $\mathrm{x}$ \\
\hline \multirow[t]{3}{*}{ DBS $^{-}$} & $\mathrm{C}_{14} \mathrm{H}_{29}$ & $\checkmark$ & $\checkmark$ & $\mathrm{x}$ & $\checkmark$ & $\checkmark$ & $\mathrm{x}$ & $\checkmark$ & $\mathrm{x}$ \\
\hline & $\mathrm{C}_{16} \mathrm{H}_{33}$ & $\checkmark$ & $\nu$ & $\sim$ & $\checkmark$ & $\checkmark$ & $\checkmark$ & $\checkmark$ & $\mathrm{x}$ \\
\hline & $\mathrm{C}_{18} \mathrm{H}_{37}$ & $\checkmark$ & $\checkmark$ & $\sim$ & $\checkmark$ & $\checkmark$ & $\checkmark$ & $\checkmark$ & $\mathrm{x}$ \\
\hline
\end{tabular}

$\checkmark$ Soluble (10 mg of complex could be dissolved completely in $1 \mathrm{~mL}$ of solvent), slightly soluble (10 mg of complex could be dissolved partly in $1 \mathrm{~mL}$ of solvent), $\mathrm{x}$ insoluble. Solutions in non-chlorinated solvents were pink at room temperature whereas solutions in chlorinated solvents were colorless. Solutions in non-chlorinated solvents were pink at room temperature whereas solutions in chlorinated solvents were colorless $\mathrm{Et}_{2} \mathrm{O}$ diethyl ether, $\mathrm{THF}$ tetrahydrofuran, $\mathrm{EtOH}$ ethanol, $\mathrm{MeOH}$ methanol

a Treated at $80{ }^{\circ} \mathrm{C}$ (in case of solubility, the solution stayed clear upon subsequent cooling to room temperature)

b Insoluble also at $80{ }^{\circ} \mathrm{C}$

unknown and alternative reasonings were proposed, such as a change in the crystal structure [33]. The latter, of course, is not plausible in solution. Finally, on the other hand preparation of fibers which show spin-crossover near room temperature from such solutions was explored. Such fibers might be useful in textile materials and caps for esthetic and functional design or as temperature indicators for non-destructive testing [37], or as filaments in security protection applications such as document authentication.

For the investigations described in the following, we chose $\mathrm{Fe}^{2+}$ complexes containing triazole ligands with alkyl chain lengths between $\mathrm{C}_{14}$ and $\mathrm{C}_{18}\left(\mathrm{C}_{14}\right.$ trz: 4-tetradecyl-1,2,4-triazole, $\mathrm{C}_{16}$ trz: 4-hexadecyl-1,2,4-triazole, and $\mathrm{C}_{18}$ trz: 4-octadecyl-1,2,4-triazole) and two different counter ions, i.e., 2-naphthalenesulfonate $\left(2 \mathrm{~ns}^{-}\right)$and 4-dodecylbenzenesulfonate $\left(\mathrm{DBS}^{-}\right)$. Both counter ions lead to a spin-crossover near room temperature.

\section{Experimental}

General

L-Ascorbic acid was purchased from Hänseler AG (Herisau, Switzerland), molecular sieve ( $3 \AA$ ) from $\mathrm{ABCR}$ GmbH \& Co. (Karlsruhe, Germany). Ultra-high molecular weight polyethylene (GUR 4120) was received from Ticona (Oberhausen, Germany).

The triazole ligands were synthesized according to the Bayer synthesis [38]. $\mathrm{Fe}^{2+}$-triazole complexes with the counter ions $2 \mathrm{~ns}^{-}$and $\mathrm{DBS}^{-}$were obtained by combination of the corresponding iron salts with the various ligands in methanol, similar to other complexes [9]. A detailed synthesis procedure is provided in the Electronic Supporting Information.

\section{Solubility}

For solubility tests, $10 \mathrm{mg}$ of the complex was exposed to $1 \mathrm{~mL}$ of the respective solvent (Table 2) and stirred for $2 \mathrm{~h}$. Toluene, xylene, and water were thereby heated to $80{ }^{\circ} \mathrm{C}$. Tests in other solvents were carried out at room temperature.

Preparation of $\mathrm{Fe}^{2+}$-triazole solutions

The procedure to prepare solutions of the various complexes with precise water content is described in the following for a $0.020 \mathrm{~mol} / \mathrm{L}\left[\mathrm{Fe}\left(\mathrm{C}_{18} \mathrm{trz}\right)_{3}\right](\mathrm{DBS})_{2}$ solution with 1 equiv. of water relative to iron as an example. $\left[\mathrm{Fe}\left(\mathrm{C}_{18} \mathrm{trz}\right)_{3}\right](\mathrm{DBS})_{2}(2.0058 \mathrm{~g}, 1.20 \mathrm{mmol})$ was dissolved in the presence of ascorbic acid $(0.24 \mathrm{mmol}, 42.7 \mathrm{mg})$ under nitrogen in degassed toluene $(60 \mathrm{~mL})$ at $65^{\circ} \mathrm{C}$ for $30 \mathrm{~min}$ resulting in a $0.020 \mathrm{~mol} / \mathrm{L}$ solution $(3.7 \% \mathrm{~m} / \mathrm{m})$. Molecular sieve ( $3 \AA$ ) was added and the mixture was again stirred for $30 \mathrm{~min}$ at $65{ }^{\circ} \mathrm{C} .48 .470 \mathrm{~g}$ of the solution was thereafter transferred without molecular sieve to a dry flask under nitrogen atmosphere. This yielded in a total amount of iron of $1.1 \mathrm{mmol}$. Water $(20 \mu \mathrm{L}, 1.1 \mathrm{mmol})$ was added with a microliter syringe. The solution was then heated to $60{ }^{\circ} \mathrm{C}$, put into an ultrasonic bath for $1 \mathrm{~min}$ and vigorously stirred for $5 \mathrm{~min}$ at $60{ }^{\circ} \mathrm{C}$. For UV/Vis measurements, the solution was transferred into a sealed dry quartz glass cuvette equipped with a septum.

All other solutions of complexes with the counter anion DBS $^{-}$were prepared analogously. Due to the reduced solubility of $\left[\mathrm{Fe}\left(\mathrm{C}_{14} \mathrm{trz}\right)_{3}\right](2 \mathrm{~ns})_{2}$ in toluene, the complex was dissolved at a higher temperature $\left(110^{\circ} \mathrm{C}\right)$ under reflux and a lower concentration was employed (0.005 mol/L). 
Preparation of fibers

A $16.7 \% \mathrm{~m} / \mathrm{m}$ blend of $\left[\mathrm{Fe}\left(\mathrm{C}_{18} \mathrm{trz}\right)_{3}\right](\mathrm{DBS})_{2}$ in polyethylene was obtained as follows. $\left[\mathrm{Fe}\left(\mathrm{C}_{18} \mathrm{trz}\right)_{3}\right](\mathrm{DBS})_{2}$ (43 mg, $0.026 \mathrm{mmol}$ ) was dissolved under nitrogen in degassed xylene (mixture of isomers) and mixed with a solution of $215 \mathrm{mg}$ UHMWPE in $40 \mathrm{~mL}$ degassed xylene at $\sim 80^{\circ} \mathrm{C}$. Blends with mass percentages of 50 and $80 \%$ $\mathrm{m} / \mathrm{m}$ of $\left[\mathrm{Fe}\left(\mathrm{C}_{18} \mathrm{trz}\right)_{3}\right](\mathrm{DBS})_{2}$ were obtained analogously. With a spatula fibers were drawn from the hot $\left(\sim 80^{\circ} \mathrm{C}\right)$ viscous solutions which were dried in air for $4 \mathrm{~h}$.

\section{Analysis}

Infrared spectra were recorded with a Bruker Vertex 70 FTIR spectrometer. Midinfrared (MIR) spectra were obtained in $\mathrm{KBr}$ with a DLaTGS detector in the range of $4000-370 \mathrm{~cm}^{-1}$ and far-infrared (FIR) spectra in CsI pellets with a DTGS detector in the range of $600-60 \mathrm{~cm}^{-1}$. Intensities are described by w: weak, m: medium, and $\mathrm{s}$ : strong.

Differential scanning calorimetry (DSC) was carried out with a DSC 822 (Mettler Toledo) instrument under nitrogen atmosphere at a heating rate of $10{ }^{\circ} \mathrm{C} / \mathrm{min}$.

$\mathrm{UV} / \mathrm{Vis}$ spectra at variable temperature were recorded with a temperature-controlled JASCO V-670 spectrometer. Spectra were taken between 70 and $-5{ }^{\circ} \mathrm{C}$ in steps of $5{ }^{\circ} \mathrm{C}$ in a wavelength region of $400-800 \mathrm{~nm}$. The samples were held for $3 \mathrm{~min}$ at the respective temperature before starting the measurement. The solutions were filled under nitrogen atmosphere into sealed quartz glass cuvettes equipped with a septum.

Optical microscopy was performed with a Leica DM400 M polarizing microscope.

\section{Results}

\section{General}

The solid $\left[\mathrm{Fe}\left(\mathrm{C}_{n} \text { trz }\right)_{3}\right](\mathrm{X})_{2}$ complexes (where $\mathrm{X}^{-}$is either $2 \mathrm{~ns}^{-}$or $\mathrm{DBS}^{-}$, respectively) contained between 1 and 3 water molecules per coordination unit, obviously depending on the ambient moisture. In the solid state, the complexes showed a color change from pink to white around, or slightly above room temperature (between 25 and $60{ }^{\circ} \mathrm{C}$ ). Accordingly, the three complexes with counter ion DBS $^{-}$showed an endothermal peak at around $60{ }^{\circ} \mathrm{C}$ during the first heating whereas upon subsequent cooling and heating, a reversible spin-crossover transition around $30-40{ }^{\circ} \mathrm{C}$ was found. During following heating and cooling protocols, the transition temperatures remained stable for at least four cycles. The length of the side chain did not have a major influence on the spin-crossover temperature. However, the peaks detected for compounds with the counter ion $2 \mathrm{~ns}^{-}$were very broad. In general, the spincrossover temperatures of the $2 \mathrm{~ns}^{-}$complexes were lower (around $10-20^{\circ} \mathrm{C}$ ) compared to the $\mathrm{DBS}^{-}$analogs.

\section{Solubility}

The solubility of the complexes $\left[\mathrm{Fe}\left(\mathrm{C}_{n} \text { trz }\right)_{3}\right](2 \mathrm{~ns})_{2}$ and $\left[\mathrm{Fe}\left(\mathrm{C}_{n} \text { trz }\right)_{3}\right](\mathrm{DBS})_{2} \quad\left(\mathrm{C}_{n}\right.$ trz $=4$-tetradecyl-1,2,4-triazole, 4-hexadecyl-1,2,4-triazole, and 4-octadecyl-1,2,4-triazole, $2 \mathrm{~ns}^{-}=2$-naphthalenesulfonate, $\mathrm{DBS}^{-}=4$-dodecylbenzenesulfonate) in various solvents was analyzed (Table 2) with a view to solution processing of these compounds. As dissolution in toluene and xylene was sluggish at room temperature, the related experiments were performed at $80{ }^{\circ} \mathrm{C}$. Materials which dissolved at this temperature did not precipitate when they were allowed to adopt room temperature. Such solutions were liquid at elevated temperatures (around $80{ }^{\circ} \mathrm{C}$ ) while gels formed at room temperature in the concentrations used in our experiments $(0.020-0.032 \mathrm{~mol} / \mathrm{L})$. As already mentioned in "Introduction," gel-formation of such compounds is not uncommon $[15,16,18]$. Formation of gels indicates the presence of extended polynuclear chains [14]. Against expectations, for 2 ns $^{-}$complexes with $\mathrm{C}_{16}$ and $\mathrm{C}_{18}$ side chains solely chloroform was a good solvent whereas only slight solubility was found in xylene, toluene, and THF and no solubility at all in heptane, diethyl ether, and alcohols. The related complex with shorter alkyl groups, $\left[\mathrm{Fe}\left(\mathrm{C}_{14}\right.\right.$ trz $\left.)_{3}\right](2 \mathrm{~ns})_{2}$, showed similar solubility in most of these solvents, except for toluene which provided significantly higher solubility for this complex, while the contrary was found in THF where the complex with $\mathrm{C}_{14}$ trz was completely insoluble. Complexes with the counter ion $\mathrm{DBS}^{-}$ and $\mathrm{C}_{16}$ and $\mathrm{C}_{18}$ side chains were better soluble than the $2 \mathrm{~ns}^{-}$complexes. Thus, the former dissolved in xylene, toluene, chlorinated solvents, diethyl ether, and THF, and slightly in heptane; only in alcohols and water no solubility was found. With the shorter side chain $\mathrm{C}_{14}$, the solubility of the DBS $^{-}$complex was markedly decreased in diethyl ether and heptane. Notably, while solutions in ethers and apolar solvents were pink at room temperature, chloroform solutions were colorless. When the latter were cooled with liquid nitrogen $\left(-196{ }^{\circ} \mathrm{C}\right)$ they adopted a pink color in the frozen state. This indicates that the $\mathrm{Fe}^{2+}$ ions are in highspin state at room temperature and can adopt the low-spin state only at very low temperature in chloroform unlike in other solvents. A similar observation was described for the complex $\left[\mathrm{Fe}(\text { doxptrz })_{3}\right](\mathrm{Cl})_{2} \quad($ doxptrz $=4$-(3-dodecyloxy)propyl-1,2,4-triazole) [39]. Solutions in dichloromethane were also colorless at room temperature but did 


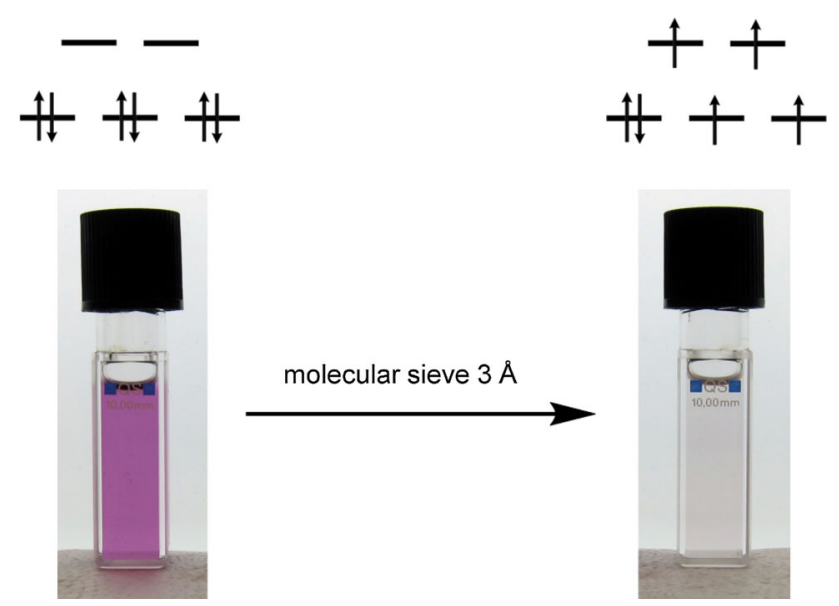

Fig. 2 Photographs of $\left[\mathrm{Fe}\left(\mathrm{C}_{16} \text { trz }\right)_{3}\right](\mathrm{DBS})_{2}$ solutions $(0.020 \mathrm{~mol} / \mathrm{L}$ in toluene) with 1 equiv. of $\mathrm{H}_{2} \mathrm{O}$ relative to $\mathrm{Fe}^{2+}$ (left) and dry (right) at room temperature (Color figure online)

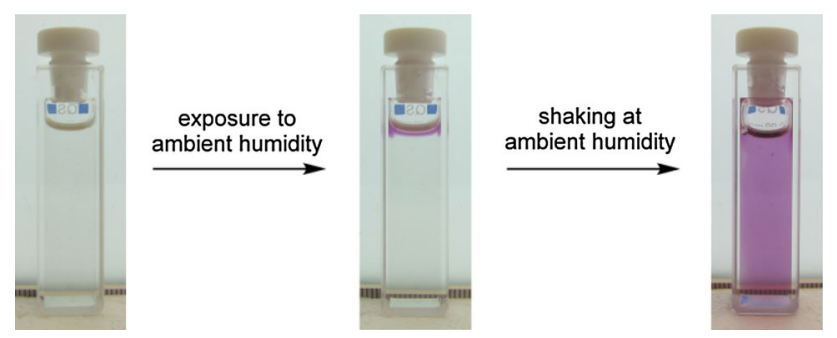

Fig. 3 Photographs of $\left[\mathrm{Fe}\left(\mathrm{C}_{18} \mathrm{trz}\right)_{3}\right](\mathrm{DBS})_{2}$ solutions $(0.016 \mathrm{~mol} / \mathrm{L}$ in toluene). Left dry, middle exposed to ambient humidity (relative humidity: $\sim 45 \%$ ) for a few minutes featuring a purple top layer, right agitated at ambient humidity (Color figure online)

not change their color when they were cooled to $-196{ }^{\circ} \mathrm{C}$ into the frozen state.

Influence of water in toluene solutions

For experiments on the potential influence of trace amounts of water on the spin-crossover in solution, toluene was selected as it was over all the best solvent for the complexes in the low-spin state at ambient temperature. Dissolving of the complexes with $\mathrm{DBS}^{-}$as counter ion in toluene resulted in pink solutions (characteristic for the low-spin state [40]). Remarkably, when the solutions were dried with molecular sieve ( $3 \AA$ ) they turned to colorless independent on the length of the alkyl group, indicating that the $\mathrm{Fe}^{2+}$ ions were mainly in the high-spin state [40] (Fig. 2 on the example of $\left.\left[\mathrm{Fe}\left(\mathrm{C}_{16} \mathrm{trz}\right)_{3}\right](\mathrm{DBS})_{2}\right)$. When the dried solutions were exposed to ambient humidity (relative humidity: $\sim 45 \%$ ) for a few minutes they turned pink at the air-liquid interface and after agitation they became homogenously pink (Fig. 3). Similarly, when the solvent of a dry, colorless toluene solution of $\left[\mathrm{Fe}\left(\mathrm{C}_{18} \mathrm{trz}\right)_{3}\right](\mathrm{DBS})_{2}$ was removed under vacuum, a colorless solid was obtained which turned pink upon exposure to ambient humidity within a few seconds. Applying reduced pressure (0.1 mbar) for several hours to the pink (hydrated) solid the color did not turn to white again. Thus, the status of the toluene-dried sample was not restored by this procedure.

The influence of water in toluene solutions on the spin state was studied in detail by optical absorption spectroscopy of solutions with defined water content. For this purpose, solutions were first dried with molecular sieve ( $3 \AA$ ) and subsequently a known quantity of water was added (up to 2 equiv. of water, $n_{\mathrm{H}_{2} \mathrm{O}}$, relative to $\mathrm{Fe}^{2+}$ ). The resulting solutions were transferred under nitrogen into sealed quartz glass cuvettes. Spectra were recorded at different temperatures between 400 and $800 \mathrm{~nm}$, which took approximately $1 \mathrm{~min}$ per scan. In order to establish constant temperature in the course of each scan, the temperature was changed stepwise (i.e., not continuously). Spectra were recorded upon cooling from 70 to $-5^{\circ} \mathrm{C}$ (preliminary experiments revealed that the reproducibility during cooling was higher compared to heating) in steps of $5{ }^{\circ} \mathrm{C}$ and the temperature was held for $3 \mathrm{~min}$ before recording of the spectra. During the temperature adjustment of the sample, fluctuations of $\pm 3{ }^{\circ} \mathrm{C}$ below and above the target temperature occurred. Therefore, with this method a potential hysteresis in the order of a few degree Celsius cannot be detected.

First, a $0.020 \mathrm{~mol} / \mathrm{L}$ solution of $\left[\mathrm{Fe}\left(\mathrm{C}_{18} \mathrm{trz}\right)_{3}\right](\mathrm{DBS})_{2}$ in toluene with 1 equiv. of water was analyzed (Fig. 4). At $70{ }^{\circ} \mathrm{C}$, no significant absorption band was observed in the visible wavelength range. N.B. a weak broad absorption band between 700 and $1000 \mathrm{~nm}$ was observed which is characteristic for the high-spin state. Accordingly, a pseudo-isosbestic point was also found at $685 \mathrm{~nm}$ upon the spin-crossover conversion from high-spin to low-spin. When the temperature was decreased to $45^{\circ} \mathrm{C}$, an absorption band with a maximum at $536 \mathrm{~nm}$ started to emerge pronouncedly which increased fast down to a temperature of $\sim 15^{\circ} \mathrm{C}$. Below this temperature only a slight increase of the absorption was found, down to $-5{ }^{\circ} \mathrm{C}$.

The measurements were repeated for solutions with varying water content. In the presence of 2 equiv. of water per $\mathrm{Fe}^{2+}$ ion, the absorbance at $536 \mathrm{~nm}$ started to increase significantly upon cooling already at $\sim 55^{\circ} \mathrm{C}$, whereas at lower water contents the absorption band started to emerge only at lower temperatures $\left(\sim 25^{\circ} \mathrm{C}\right.$ in the case of $\left.n_{\mathrm{H}_{2} \mathrm{O}}=0\right)$. Hence, while the completely dried solution showed negligible absorbance at $536 \mathrm{~nm}$ at room temperature and thus appeared virtually colorless, the solution 
Fig. 4 Temperature-dependent $\mathrm{UV} / \mathrm{V}$ is measurements of $\left[\mathrm{Fe}\left(\mathrm{C}_{18} \mathrm{trz}\right)_{3}\right](\mathrm{DBS})_{2}$ in toluene $(0.020 \mathrm{~mol} / \mathrm{L})$. a Spectra of a solution with 1 equiv. of $\mathrm{H}_{2} \mathrm{O}$ per $\mathrm{Fe}^{2+}$ upon cooling from 70 to $-5{ }^{\circ} \mathrm{C}$ (from bottom to top) in steps of $5{ }^{\circ} \mathrm{C}$. b-

d Absorbance at $536 \mathrm{~nm}$ of solutions with different water content at different temperatures. Black dots dry solution, red dots 0.5 equiv. of $\mathrm{H}_{2} \mathrm{O}$ per $\mathrm{Fe}^{2+}$, green dots 0.75 equiv. of $\mathrm{H}_{2} \mathrm{O}$ per $\mathrm{Fe}^{2+}$, blue dots 1 equiv. of $\mathrm{H}_{2} \mathrm{O}$ per $\mathrm{Fe}^{2+}$, and pink dots 2 eq $\mathrm{H}_{2} \mathrm{O}$ per $\mathrm{Fe}^{2+}$ at different $\mathrm{Fe}^{2+}$ concentrations $(0.020,0.026$, and $0.032 \mathrm{~mol} / \mathrm{L})($ Color figure online)
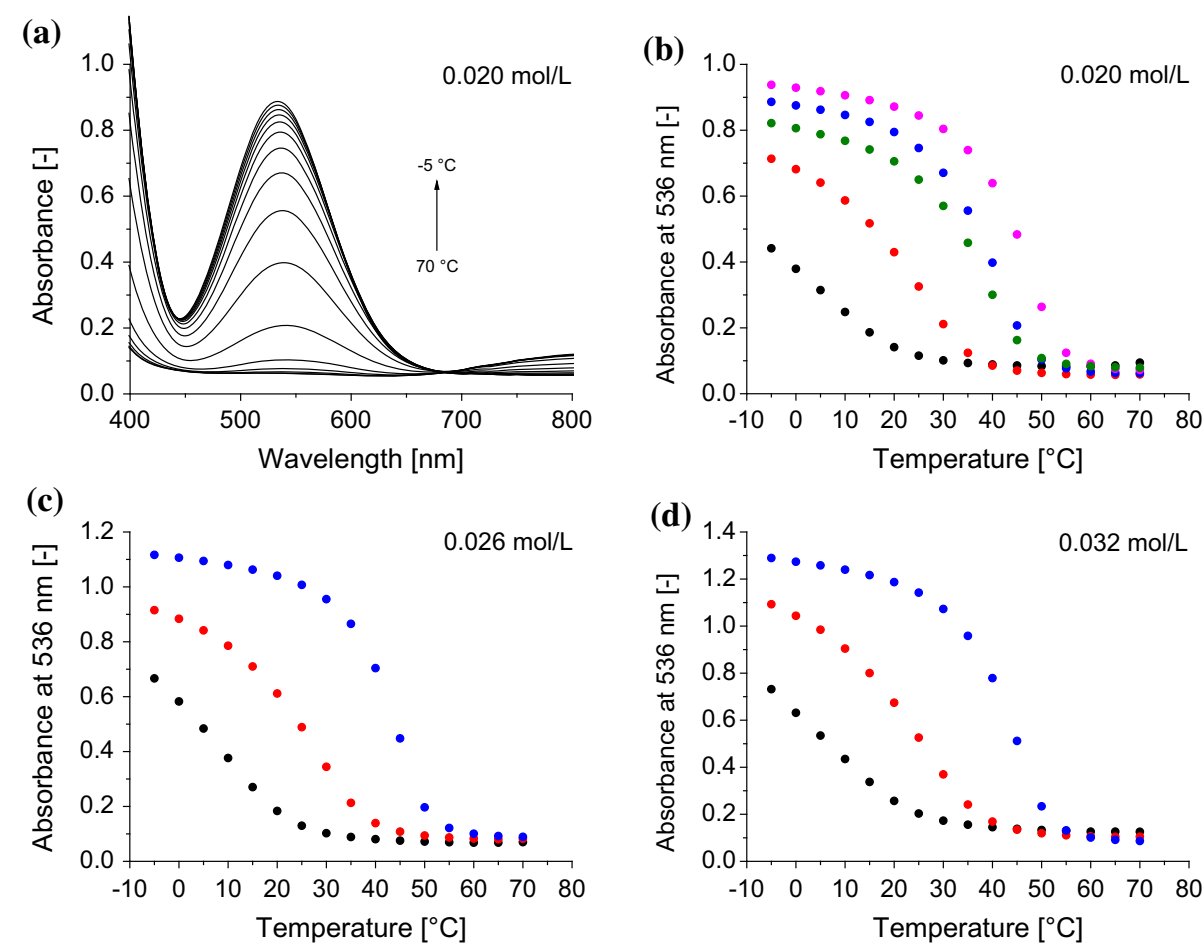

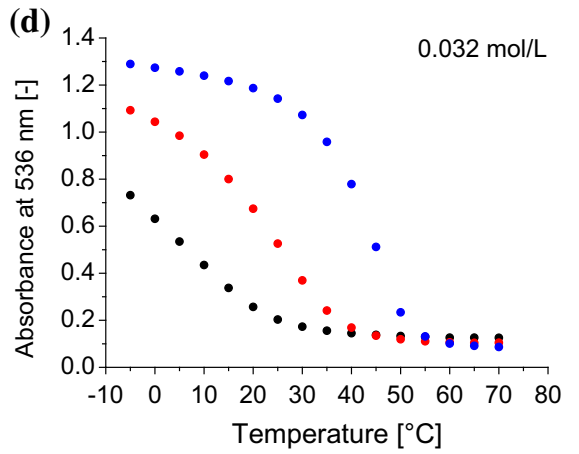

containing 2 equiv. of water had reached already a high absorbance value at room temperature and appeared pink. For convenience, the absorbance at the absorption maximum $(536 \mathrm{~nm})$ of solutions with different water content is plotted versus the temperature and shown in Fig. 4. It is evident that the transition temperature from the low-spin state to the high-spin state strongly depends on the water content and is shifted continuously toward significantly higher temperatures when the amount of water per $\mathrm{Fe}^{2+}$ ion is increased. Thus, small amounts of water stabilize the low-spin state. Notably, in the case of hydrolysis of the complexes the high-spin state would be stabilized [41]. The latter was observed in the compound $\left[\mathrm{Fe}\left(\mathrm{NH}_{2} \mathrm{trz}\right)_{3}\right] \mathrm{Br}_{2}$, where dissociation of the complex occurs by addition of water at concomitant formation of the high-spin state [41].

Analogous measurements were carried out for $\left[\mathrm{Fe}\left(\mathrm{C}_{18}\right.\right.$ trz $\left.)_{3}\right](\mathrm{DBS})_{2}$ solutions at higher concentrations (0.026 and $0.032 \mathrm{~mol} / \mathrm{L}$ ). The corresponding absorbance values at $536 \mathrm{~nm}$ as function of temperature are shown in Fig. 4. At given $\mathrm{Fe}^{2+} / \mathrm{H}_{2} \mathrm{O}$ ratios, the increase in intensity was essentially proportional to the increase in concentration according to the law of Bouguer-Lambert-Beer [42-44]. The inflection points of the temperature-dependent absorbances at $536 \mathrm{~nm}$, in the following denoted as spin-crossover temperatures, are listed in Table 3 (the inflection point has been selected as it is mathematically well defined; the number of high-spin and low-spin states can differ at his point). Obviously, the spin-crossover temperature increased over a range of $40{ }^{\circ} \mathrm{C}$ with increasing $\mathrm{Fe}^{2+} / \mathrm{H}_{2} \mathrm{O}$
Table 3 Spin-crossover temperatures (in ${ }^{\circ} \mathrm{C}$ ) determined by the inflection point of temperature-dependent optical absorbances at the maximum absorption wavelength of $\left[\mathrm{Fe}\left(\mathrm{C}_{18} \text { trz }\right)_{3}\right](\mathrm{DBS})_{2}$ solutions in toluene with different $\mathrm{Fe}^{2+}$ concentrations $\left(c_{\mathrm{Fe}^{2+}}\right)$ and equivalents of $\mathrm{H}_{2} \mathrm{O}\left(n_{\mathrm{H}_{2} \mathrm{O}}\right)$ per $\mathrm{Fe}^{2+}$

\begin{tabular}{llll}
\hline$n_{\mathrm{H}_{2} \mathrm{O}}(-)$ & \multicolumn{3}{l}{$c_{\mathrm{Fe}^{2+}}(\mathrm{mol} / \mathrm{L})$} \\
\cline { 2 - 4 } & 0.020 & 0.026 & 0.032 \\
\hline 0 & 7 & 9 & 9 \\
0.5 & 27 & 29 & 26 \\
0.75 & 39 & - & - \\
1 & 42 & 45 & 45 \\
2 & 47 & - & - \\
\hline
\end{tabular}

ratio but was virtually independent on the $\mathrm{Fe}^{2+}$ concentration at a given $\mathrm{Fe}^{2+} / \mathrm{H}_{2} \mathrm{O}$ ratio.

For the related complexes $\left[\mathrm{Fe}\left(\mathrm{C}_{16} \mathrm{trz}\right)_{3}\right](\mathrm{DBS})_{2}$ and $\left[\mathrm{Fe}\left(\mathrm{C}_{14} \mathrm{trz}\right)_{3}\right](\mathrm{DBS})_{2}$ optical absorption spectra were recorded of dry solutions and solutions containing 1 equiv. of water per $\mathrm{Fe}^{2+}$ ion at a concentration of $0.020 \mathrm{~mol} / \mathrm{L}$. No significant difference in the spectra could be found compared to those obtained for $\left.\left[\mathrm{Fe}\left(\mathrm{C}_{18} \mathrm{trz}\right)_{3}\right](\mathrm{DBS})_{2}\right]$, neither in the maximum absorbance wavelength nor in the intensity. The respective values of the spin-crossover temperatures are listed in Table 4 together with the corresponding values of $\left[\mathrm{Fe}\left(\mathrm{C}_{18} \mathrm{trz}\right)_{3}\right](\mathrm{DBS})_{2}$ for comparison. Evidently, a change in the length of the alkyl chain in the investigated range of tetradecyl-octadecyl did not 
Table 4 Comparison of the spin-crossover temperatures (in ${ }^{\circ} \mathrm{C}$ ) determined by the inflection point of temperature-dependent optical absorbances at the maximum absorption wavelength $(536 \mathrm{~nm})$ of $\mathrm{Fe}^{2+}$-triazole solutions in toluene (at a $\mathrm{Fe}^{2+}$ concentration of $0.020 \mathrm{~mol} / \mathrm{L}$ for $\mathrm{DBS}^{-}$complexes and $0.005 \mathrm{~mol} / \mathrm{L}$ for the $2 \mathrm{~ns}^{-}$ complex)

\begin{tabular}{lcc}
\hline Complex & $n_{\mathrm{H}_{2} \mathrm{O}}(-)$ & \\
\cline { 2 - 3 } & 0 & 1 \\
\hline$\left[\mathrm{Fe}\left(\mathrm{C}_{14} \mathrm{trz}\right)_{3}\right](\mathrm{DBS})_{2}$ & 5 & 40 \\
{$\left[\mathrm{Fe}\left(\mathrm{C}_{16} \mathrm{trz}\right)_{3}\right](\mathrm{DBS})_{2}$} & 6 & 41 \\
{$\left[\mathrm{Fe}\left(\mathrm{C}_{18} \mathrm{trz}\right)_{3}\right](\mathrm{DBS})_{2}$} & 7 & 42 \\
{$\left[\mathrm{Fe}\left(\mathrm{C}_{14} \mathrm{trz}\right)_{3}\right](2 \mathrm{~ns})_{2}$} & 14 & 29 \\
\hline
\end{tabular}

influence the spin-crossover temperature significantly, in absence as well as in presence of water.

Since the solubility of the $2 \mathrm{~ns}^{-}$complexes was considerably lower compared to $\mathrm{DBS}^{-}$complexes, similar measurements with water could be carried out only for $\left[\mathrm{Fe}\left(\mathrm{C}_{14} \mathrm{trz}\right)_{3}\right](2 \mathrm{~ns})_{2}$, which showed higher solubility in toluene than the $2 \mathrm{~ns}^{-}$complexes with $\mathrm{C}_{16}$ trz and $\mathrm{C}_{18}$ trz. Thus, investigations were performed at a $\mathrm{Fe}^{2+}$ concentration of $0.005 \mathrm{~mol} / \mathrm{L}$ (as a side note, even at this concentration only a small fraction of complexes with $\mathrm{C}_{16}$ and $\mathrm{C}_{18}$ side chains dissolved in boiling toluene). Still, since the spin-crossover temperature of the $\mathrm{DBS}^{-}$complexes only depended on the $\mathrm{Fe}^{2+} / \mathrm{H}_{2} \mathrm{O}$ ratio but not on the concentration at given ratios, the values obtained with lower concentrated $2 \mathrm{~ns}^{-}$solutions can be compared with the higher concentrated solutions of $\mathrm{DBS}^{-}$complexes. Admittedly, however, the precision of the water content in $2 \mathrm{~ns}^{-}$solutions is lower as smaller amounts of water were added. Nevertheless, it is evident that $\left[\mathrm{Fe}\left(\mathrm{C}_{14} \mathrm{trz}\right)_{3}\right](2 \mathrm{~ns})_{2}$ exhibits a smaller difference of the spin-crossover temperatures of solutions with $n_{\mathrm{H}_{2} \mathrm{O}}=0$ and $n_{\mathrm{H}_{2} \mathrm{O}}=1$, i.e., only $\sim 15{ }^{\circ} \mathrm{C}$ compared to $\sim 35{ }^{\circ} \mathrm{C}$ in $\left[\mathrm{Fe}\left(\mathrm{C}_{14} \text { trz }\right)_{3}\right](\mathrm{DBS})_{2}$ (see Table 4). Thus, the effect of water on the spin-crossover temperature of the $2 \mathrm{~ns}^{-}$complex also existed but was less pronounced than for $\mathrm{DBS}^{-}$complexes.

Fibers of $\left[\mathrm{Fe}\left(\mathrm{C}_{18} \mathrm{trz}\right)_{3}\right](\mathrm{DBS})_{2}$-polyethylene blends

Fibers of $\left[\mathrm{Fe}\left(\mathrm{C}_{18} \mathrm{trz}\right)_{3}\right](\mathrm{DBS})_{2}$ itself could not be prepared as we were not able to obtain solutions with suitable viscosity for fiber drawing. Thus, blends of this complex with ultra-high molecular weight polyethylene (UHMWPE) as supporting matrix were prepared. UHMWPE was chosen since first, no adverse effects related to interactions between the complex and the matrix (such as coordination) are expected and second, in solution viscosity can be enhanced already at very low concentrations of this organic polymer. The complex $\left[\mathrm{Fe}\left(\mathrm{C}_{18} \mathrm{trz}\right)_{3}\right](\mathrm{DBS})_{2}$ was selected

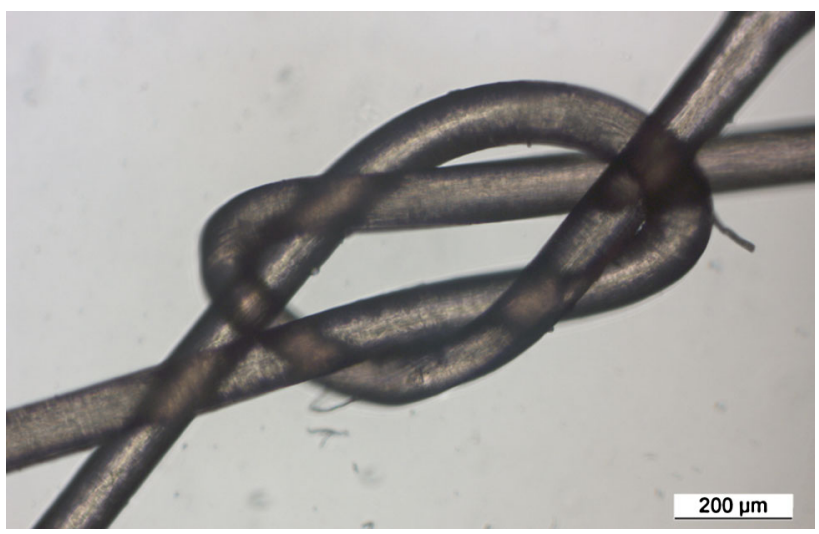

Fig. 5 Optical microscope image of two fibers of a $50 \% \mathrm{~m} / \mathrm{m}$ blend of $\left[\mathrm{Fe}\left(\mathrm{C}_{18} \mathrm{trz}\right)_{3}\right](\mathrm{DBS})_{2}$ and UHMWPE, connected with a knot

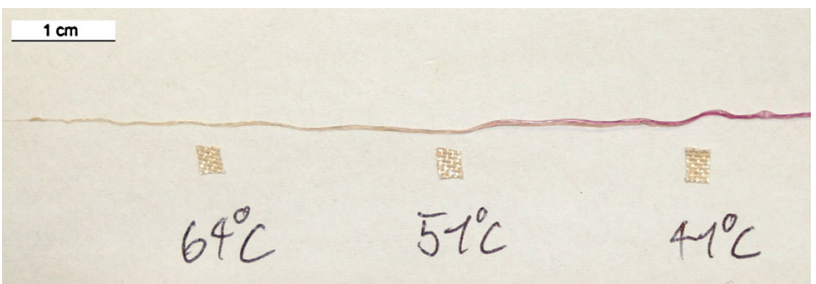

Fig. 6 Photograph of a fiber consisting of a blend of $\left[\mathrm{Fe}\left(\mathrm{C}_{18} \mathrm{trz}\right)_{3}\right]$ $(\mathrm{DBS})_{2}(80 \% \mathrm{~m} / \mathrm{m})$ and UHMWPE exposed to a temperature gradient from $\sim 25$ to $\sim 70{ }^{\circ} \mathrm{C}$. A tape with defined emissivity (beigecolored rectangles) allowed determination of the temperature with an IR-thermometer (Color figure online)

on the one hand due to its counter ion $\mathrm{DBS}^{-}$which leads to a good solubility, and on the other hand because it contains the longest alkyl chain among the investigated complexes and thus was expected to be best compatible with polyethylene. Blends were prepared at three different $\left[\mathrm{Fe}\left(\mathrm{C}_{18}\right.\right.$ trz $\left.)_{3}\right](\mathrm{DBS})_{2}$ contents (fraction of complex: 16.7, 50, and $80 \% \mathrm{~m} / \mathrm{m}$ ). For the preparation of the blends, xylene (a good solvent for UHMWPE) solutions of the two components were mixed at elevated temperature $\left(80^{\circ} \mathrm{C}\right.$; fraction of the total mass of polyethylene and complex in xylene: $0.6 \% \mathrm{~m} / \mathrm{m}$ ). The resulting viscous solutions were used to draw fibers of thicknesses between 50 and $200 \mu \mathrm{m}$ after drying in air. A microscope image of a fiber with $50 \%$ $\mathrm{m} / \mathrm{m}$ of $\left[\mathrm{Fe}\left(\mathrm{C}_{18} \mathrm{trz}\right)_{3}\right](\mathrm{DBS})_{2}$ is shown in Fig. 5. As a consequence of the poor interaction between $\left[\mathrm{Fe}\left(\mathrm{C}_{18}\right.\right.$ trz $\left.)_{3}\right](\mathrm{DBS})_{2}$ and UHMWPE thermochromism of the blend was found to occur at a similar temperature (between 40 and $50{ }^{\circ} \mathrm{C}$ ) as in the neat complex, indicative of preservation of the spin-crossover properties to a large extent. To visualize the thermochromism, a fiber with $80 \%\left[\mathrm{Fe}\left(\mathrm{C}_{18}\right.\right.$ trz $\left.)_{3}\right](\mathrm{DBS})_{2}$ was aligned on a Kofler bench featuring a temperature gradient between room temperature and $\sim 70{ }^{\circ} \mathrm{C}$ (Fig. 6). 


\section{Discussion and conclusions}

While $2 \mathrm{~ns}^{-}$complexes were poorly soluble in organic solvents, their DBS $^{-}$analogs showed a high solubility in various organic solvents which is beneficial for processing, e.g., into films, fibers, etc. Thus, the solubility of such complexes depends on the counter ions and it appears that a counter ion with alkyl groups tends to promote solubility in organic solvents. Entropy is expected to support solubility of alkyl units as their degrees of freedom are much higher in the dissolved than in the solid state. Whereas solutions of such complexes in non-chlorinated solvents were pink at room temperature, solutions in chloroform and dichloromethane were colorless. In the literature, the color change from pink to white upon dissolution of a similar complex in chloroform was ascribed to the solvation of alkyl chains and concomitant lengthening of the $\mathrm{Fe}-\mathrm{N}$ bonds leading to a lower spin-crossover temperature [39]. However, also other effects, such as interactions between the solvent and counter ions accounting for a change in the ligand field or the presence of significant amounts of water in the solvent might play a major role.

Remarkably, the spin state of $\mathrm{DBS}^{-}$complexes dissolved in toluene was found to depend on the relative water content. The spin-crossover temperature increased with increasing water content which reveals that water molecules stabilize the low-spin state. The influence of water in organic solvents has not been described so far to our knowledge (while aqueous solutions of iron(II)-aminotriazole complexes have been studied in a concentration range of $0.5-3 \% \mathrm{w} / \mathrm{w}$ ) [41]. In the solid state, possible explanations involve an impact of hydrogen-bonds $[13,31]$ or of the crystal structure [31, 33]. In solution, however, a potential impact of the crystal structure on the spin-crossover properties can be excluded whereas hydrogen-bonds might still play a major role. For comparison, 1-octanol decreased the spin-crossover temperature of $[\mathrm{Fe}(\mathrm{dox}-$ ptrz) $\left.)_{3}\right] \mathrm{Cl}_{2}$ (doxp $=4$-(3-dodecyloxy)propyl) in solution by acting as a hydrogen-bond scavenger [13]. Thus, hydrogenbond formation in such complexes can reasonably explain the stabilization of the low-spin state by water in solution. In principle, there are three possible sites for interactions of the dissolved $\left[\mathrm{Fe}\left(\mathrm{C}_{n} \text { trz }\right)_{3}\right] \mathrm{X}_{2}$ complexes with water: the $\mathrm{Fe}^{2+}$ ions, the ligands, and the counter ions. Since alkylsubstituted triazole molecules can hardly contribute to hydrogen-bonding and direct bonding of water to $\mathrm{Fe}^{2+}$ is rather improbable (in this case the high-spin state would expected to be favored [45]), the counter ions probably play a major role. Therefore, it is conceivable that water molecules interact with the counter ions by forming hydrogen bonds [13], thus modifying the ligand-field strength.
A dependence of the color on the water content was also found for $\left[\mathrm{Fe}\left(\mathrm{C}_{14} \mathrm{trz}\right)_{3}\right](2 \mathrm{~ns})_{2}$ solutions, albeit less pronounced than in solutions of $\mathrm{DBS}^{-}$complexes.

Notably, no influence of the concentration of complex was found on its spin-crossover properties which implies that there is hardly any significant dissociation equilibrium involved, unlike described for $\left[\mathrm{Fe}\left(\mathrm{NH}_{2} \mathrm{trz}\right)_{3}\right](2 \mathrm{~ns})_{2}$ solutions in DMF [12]. Hence, the findings reported here are of particular interest because the spin-crossover temperature can be tuned around room temperature by the water-tocomplex ratio-independent of the concentration of the complex. It means in effect that small amounts of water (in the range of parts per million) can be detected in organic solvents with these complexes. Such measurements can be helpful for water determination in, e.g., insulating fluids where small amounts of water can be detrimental. For such applications, compounds with the counter ion $\mathrm{DBS}^{-}$are better suited compared to those containing $2 \mathrm{~ns}^{-}$as the former show a higher solubility and a stronger influence of water compared to the investigated $2 \mathrm{~ns}^{-}$complex.

The observation that a colorless solid was obtained upon solvent removal of a dry toluene solution of $\left[\mathrm{Fe}\left(\mathrm{C}_{18}\right.\right.$ trz) $\left.{ }_{3}\right](\text { DBS })_{2}$ (which turned pink at ambient humidity) suggests that the spin-crossover depends on the water content also in the solid state. However, the hydrated (pink) form could not be converted to its dehydrated (colorless) form simply upon applying reduced pressure $(0.1 \mathrm{mbar})$. Thus, the water molecules seem to be rather strongly bound to the complex, such that they only could be removed by molecular sieve in solution in toluene.

Owing to the aforementioned high solubility of $\left[\mathrm{Fe}\left(\mathrm{C}_{18} \mathrm{trz}\right)_{3}\right](\mathrm{DBS})_{2}$, it was possible to manufacture fibers from blends with UHMWPE by simple drawing from solution. Strikingly, the spin-crossover properties were preserved in fibers and the thermochromism was found to occur at a similar temperature as in the pure complex which indicates that the hydrophobic environment of the matrix had virtually no influence on the amount of noncoordinated water in the complex.

Acknowledgements We thankfully acknowledge Dr. Martin Willeke for valuable advice regarding this study and for providing access to a temperature-controllable UV/Vis spectrometer. Furthermore, we thank the Swiss National Science Foundation (No. 200021_137550) for financial support and the COST Action CM1302 "European Network on Smart Inorganic Polymers (SIPs)" as a platform for inspiration.

\section{References}

1. Gütlich P, Hauser A (1990) Thermal and light-induced spin crossover in iron(II) complexes. Coord Chem Rev 97:1-22 
2. Moussa NO, Ostrovskii D, Martinez Garcia V, Molnár G, Tanaka K, Gaspar AB, Real JA, Bousseksou A (2009) Bidirectional photo-switching of the spin state of iron(II) ions in a triazol based spin crossover complex within the thermal hysteresis loop. Chem Phys Lett 477:156-159

3. Gaspar AB, Levchenko G, Terekhov S, Bukin G, Valverde-Muñoz J, Muñoz-Lara FJ, Seredyuk M, Real JA (2014) The effect of pressure on the cooperative spin transition in the 2D coordination polymer $\left\{\mathrm{Fe}(\mathrm{phpy})_{2}\left[\mathrm{Ni}(\mathrm{CN})_{4}\right]\right\}$. Eur J Inorg Chem 3:429-433

4. Roubeau O (2012) Triazole-based one-dimensional spin-crossover coordination polymers. Chem Eur J 18:15230-15244

5. Kahn O, Codjovi E (1996) Iron(II)-1,2,4-triazole spin transition molecular materials. Philos Trans R Soc Lond A 354:359-379

6. Kröber J, Codjovi E, Kahn O, Grolière F, Jay C (1993) A spin transition system with a thermal hysteresis at room temperature. J Am Chem Soc 115:9810-9811

7. Kröber J, Audière JP, Claude R, Codjovi E, Kahn O (1994) Spin transitions and thermal hysteresis in the molecular-based materials $\left[\mathrm{Fe}(\mathrm{Htrz})_{2}(\mathrm{trz})\right]\left(\mathrm{BF}_{4}\right)$ and $\left[\mathrm{Fe}(\mathrm{Htrz})_{3}\right]\left(\mathrm{BF}_{4}\right)_{2} \cdot \mathrm{H}_{2} \mathrm{O}(\mathrm{Htrz}=$ 1,2,4-4H-triazole; trz $=1,2,4$-triazolato). Chem Mater 6:14041412

8. Sugiyarto KH, Goodwin HA (1994) Cooperative spin transitions in iron(II) derivatives of 1,2,4-triazole. Aust J Chem 47:263-277

9. van Koningsbrugen PJ, Garcia Y, Codjovi E, Lapouyade R, Kahn O, Fournès L, Rabardel L (1997) Non-classical Fe ${ }^{\mathrm{II}}$ spin-crossover behaviour in polymeric iron(II) compounds of formula [Fe $\left.\left(\mathrm{NH}_{2} \text { trz }\right)_{3}\right] \mathrm{X}_{2} x \mathrm{H}_{2} \mathrm{O} \quad\left(\mathrm{NH}_{2}\right.$ trz $=4$-amino-1,2,4-triazole; $\quad \mathrm{X}=$ derivatives of naphthalene sulfonate). J Mater Chem 7:20692075

10. Dîrtu MM, Garcia Y, Nica M, Rotaru A, Linares J, Varret F (2007) Iron(II) spin transition 1,2,4-triazole chain compounds with novel inorganic fluorinated counteranions. Polyhedron 26:2259-2263

11. Bausk NV, Érenburg SB, Mazalov LN, Lavrenova LG, Ikorskii VN (1994) Electronic and spatial structure of spin transition iron(II) tris(4-amino-1,2,4-triazole) nitrate and perchlorate complexes. J Struct Chem 35:509-516

12. Bräunlich I, Sánchez-Ferrer A, Bauer M, Schepper R, Knüsel P, Dshemuchadse J, Mezzenga R, Caseri W (2014) Polynuclear iron(II)-aminotriazole spincrossover complexes (polymers) in solution. Inorg Chem 53:3546-3557

13. Fujigaya T, Jiang DL, Aida T (2007) Spin-crossover physical gels: a quick thermoreversible response assisted by dynamic selforganization. Chem Asian J 2:106-113

14. Grondin P, Roubeau O, Castro M, Saadaoui H, Colin A, Clérac R (2010) Multifunctional gels from polymeric spin-crossover metallo-gelators. Langmuir 26:5184-5195

15. Rubio M, López D (2009) Effect of solvent on the gelation properties of a metallo-organic polymer of [Fe(II) (4-octadecyl1,2,4-triazole $\left.)_{3}\left(\mathrm{ClO}_{4}\right)_{2}\right]_{n}$. Eur Polym J 45:3339-3346

16. Kuroiwa K, Shibata T, Sasaki S, Ohba M, Takahara A, Kunitake T, Kimizuka N (2006) Supramolecular control of spin-crossover phenomena in lipophilic Fe(II)-1,2,4-triazole complexes. J Polym Sci A 44:5192-5202

17. Roubeau O, Colin A, Schmitt V, Clérac R (2004) Thermoreversible gels as magneto-optical switches. Angew Chem Int Ed 43:3283-3286

18. Roubeau O, Alcazar Gomez JM, Balskus E, Kolnaar JJA, Haasnoot JG, Reedijk J (2001) Spin-transition behaviour in chains of $\mathrm{Fe}^{\mathrm{II}}$ bridged by 4 -substituted 1,2,4-triazoles carrying alkyl tails. New J Chem 25:144-150

19. Armand F, Badoux C, Bonville P, Ruaudel-Teixier A, Kahn O (1995) Langmuir-blodgett films of spin transition iron(II) metalloorganic polymers. 1. Iron(II) complexes of octadecyl-1,2,4triazole. Langmuir 11:3467-3472
20. Roubeau O, Agricole B, Clérac R, Ravaine S (2004) Triazolebased magnetic langmuir-blodgett films: paramagnetic to spincrossover behavior. J Phys Chem B 108:15110-15116

21. Roubeau O, Natividad E, Agricole B, Ravaine S (2007) Formation, structure, and morphology of triazole-based langmuirblodgett films. Langmuir 23:3110-3117

22. Grondin P, Siretanu D, Roubeau O, Achard MF, Clérac R (2012) Liquid-crystalline zinc(II) and iron(II) alkyltriazoles one-dimensional coordination polymers. Inorg Chem 51:5417-5426

23. Fujigaya T, Jiang DL, Aida T (2003) Switching of spin states triggered by a phase transition: spin-crossover properties of selfassembled iron(II) complexes with alkyl-tethered triazole ligands. J Am Chem Soc 125:14690-14691

24. Matsukizono H, Kuroiwa K, Kimizuka N (2008) Self-assemblydirected spin conversion of iron(II)-1,2,4-triazole complexes in solution and their effect on photorelaxation processes of fluorescent counter ions. Chem Lett 37:446-447

25. Lee YH, Komatsu Y, Yamamoto Y, Kato K, Shimizu T, Ohta A, Matsui T, Hayami S (2011) Spin crossover polymeric iron(II) complex based on triazole with branched long alkyl chain. Inorg Chem Commun 14:1498-1500

26. Yokoyama T, Murakami Y, Kiguchi M, Komatsu T, Kojima N (1998) Spin-crossover phase transition of a chain Fe(II) complex studied by X-ray-absorption fine-structure spectroscopy. Phys Rev B 58:14238-14244

27. Gaspar AB, Seredyuk M (2014) Spin crossover in soft matter. Coord Chem Rev 268:41-58

28. Lee SW, Lee JW, Jeong SH, Park IW, Kim YM, Jin JI (2004) Processable magnetic plastics composites-spin crossover of PMMA/Fe(II)-complexes composites. Synth Met 142:243-249

29. Rubio M, Hernández R, Nogales A, Roig A, López D (2011) Structure of a spin-crossover Fe(II)-1,2,4-triazole polymer complex dispersed in an isotactic polystyrene matrix. Eur Polym J 47:52-60

30. Jeong SH, Kim KN, Kang JS, Hong CS, Choi DH, Jin JI (2007) Storing spin-crossover and LC phase transitions information by hybridizing spin-crossover complexes with a thermotropic polymer matrix - a novel case of multiple switching. Mol Cryst Liq Cryst 471:3-10

31. Roubeau O, Haasnoot JG, Codjovi E, Varret F, Reedijk J (2002) Spin transition regime in new one-dimensional polymeric iron(II) compounds. Importance of the water content for the thermal and optical properties. Chem Mater 14:2559-2566

32. Garcia Y, van Koningsbruggen PJ, Lapouyade R, Fournès L, Rabardel L, Kahn O, Ksenofontov V, Levchenko G, Gütlich P (1998) Influences of temperature, pressure, and lattice solvents on the spin transition regime of the polymeric compound [Fe(hyetrz) $\left.{ }_{3}\right] \mathrm{A}_{2} \cdot 3 \mathrm{H}_{2} \mathrm{O}$ (hyetrz $=4$-(2'-hydroxyethyl)-1,2,4-triazole and $\mathrm{A}^{-}=3$-nitrophenylsulfonate). Chem Mater 10:2426-2433

33. Garcia Y, van Koningsbruggen PJ, Lapouyade R, Rabardel L, Kahn O, Wieczorek M, Bronisz R, Ciunik Z, Rudolf MF (1998) Synthesis and spin-crossover characteristics of polynuclear 4-(2'hydroxy-ethyl)-1,2,4-triazole $\mathrm{Fe}(\mathrm{II})$ molecular materials. C R Acad Sci IIc Chim 1:523-532

34. Muñoz-Lara FJ, Gaspar AB, Muñoz MC, Lysenko AB, Domasevitch KV, Real JA (2012) Fast detection of water and organic molecules by a change of color in an iron(II) microporous spincrossover coordination polymer. Inorg Chem 51:13078-13080

35. Muñoz Lara FJ, Gaspar AB, Aravena D, Ruiz E, Muñoz MC, Ohba M, Ohtani R, Kitagawa S, Real JA (2012) Enhanced bistability by guest inclusion in $\mathrm{Fe}(\mathrm{II})$ spin crossover porous coordination polymers. Chem Commun 48:4686-4688

36. Roubeau O, Castro M, Burriel R, Haasnoot JG, Reedijk J (2011) Calorimetric investigation of triazole-bridged $\mathrm{Fe}(\mathrm{II})$ spin-crossover one-dimensional materials: measuring the cooperativity. Phys Chem B 115:3003-3012 
37. Chowdhury MA, Joshi M, Butola BS (2014) Photochromic and thermochromic colorants in textile applications. J Eng Fibers Fabrics 9:107-123

38. Bayer HO, Cook RS, Von Meyer WC (1974) Fungicidal use of a 1,2,4-triazole nickel salt complex. US Patent 3,821,376, June 28, 1974

39. Kuroiwa K, Kikuchi H, Kimizuka N (2010) Spin crossover characteristics of nanofibrous $\mathrm{Fe}^{\mathrm{II}}-1,2,4$-triazole complexes in liquid crystals. Chem Commun 46:1229-1231

40. Dîrtu MM, Neuhausen C, Naik AD, Rotaru A, Spinu L, Garcia Y (2010) Insights into the origin of cooperative effects in the spin transition of $\left[\mathrm{Fe}\left(\mathrm{NH}_{2} \mathrm{trz}\right)_{3}\right]\left(\mathrm{NO}_{3}\right)_{2}$ : the role of supramolecular interactions evidenced in the crystal structure of $\left[\mathrm{Cu}\left(\mathrm{NH}_{2}\right.\right.$ trz $\left.)_{3}\right]\left(\mathrm{NO}_{3}\right)_{2} \cdot \mathrm{H}_{2} \mathrm{O}$. Inorg Chem 49:5723-5736

41. Ikorskii VN (2001) Effect of water on spin transitions in $\mathrm{Fe}(\mathrm{II})$ complexes with triazoles. Dokl Phys Chem 377:77-79
42. Bouguer (initials not indicated in the original article) (1729) Essai d'optique sur la gradation de la lumiere, Claude Jombert, Paris

43. Lambert IH (1760) Photometria sive de Mensura et Gradibus Lumnis, Colorum et Umbrae, Eberhardt Klett (printer C. P. Detlefsen), Augusta Vindelicorum (Augsburg)

44. Beer (initials not indicated in the original article) (1852) Bestimmung der Absorption des rothen Lichts in farbigen Flüssigkeiten. Pogg Ann 86:78-88

45. Garcia Y, Guionneau P, Bravic G, Chasseau D, Howard JAK, Kahn O, Ksenofontov V, Reiman S, Gütlich P (2000) Synthesis, crystal structure, magnetic properties and ${ }^{57} \mathrm{Fe}$ Mössbauer spectroscopy of the new trinuclear $\left[\mathrm{Fe}_{3}\left(4-\left(2^{\prime}\right.\right.\right.$-hydroxyethyl $)-1,2,4-$ triazole $\left.)_{6}\left(\mathrm{H}_{2} \mathrm{O}\right)_{6}\right]\left(\mathrm{CF}_{3} \mathrm{SO}_{3}\right)_{6}$ spin crossover compound. Eur J Inorg Chem 7:1531-1538 